\title{
Linguistic Prehistory and Identity in Nigeria's Bini-Ife Pre-eminence Contestation
}

\author{
Demola Lewis \\ University of Ibadan
}

\begin{abstract}
On the basis of genetic classification, Edoid (of the Bini people of Nigeria) is conceived as an offshoot of Benue-Congo earlier than Yoruboid (of the Ife people of Nigeria). However, the reverse is the case when viewed from the sociolinguistic platforms of population, prestige and power. Thus, in 2004, the Edoid patriarch of Bini launched a biography, wherein he narrated the Bini origin of the Ife monarchy. This sparked a barrage of unguarded responses from both sides of the controversy, largely centred on different interpretations to oral tradition. By exploring language as custodian of prehistory, this paper makes a linguistic contribution to the continuing debate about which predates the other between Ife (Yoruboid) and Bini (Edoid) of southwestern Nigeria. It pieces together evidence of cognate lexical simplification, patterns of cognate counting systems, sound inventory, and decadence of vowel harmony, which support the chronological pre-eminence of Edoid over Yoruboid; thus, calling for archaeological, anthropological and geographical inspection.
\end{abstract}

Keywords: Prehistory, Pre-eminence contestation, Bini-Ife, Edoid, Yoruboid

\section{INTRODUCTION}

There are two main concerns of comparative historical linguistics, namely the determination of genetic linguistic relatedness and the illumination of prehistories, otherwise known as linguistic palaeontology. The first of these has been robustly explored, to the extent that there are gross phylogenetic trees to which most natural languages have been parsed (Greenberg, 1963; Guthrie, 1971; Blust, 1995). However, scant attempts have been made (especially in recent time) to reconstruct specific historical events through linguistic inferences. In the case of Africa, some such attempts include the routing of the migration of Niger-Congo populations to their current location in West Africa (Heine, 1979; Horton, 1982 and Elugbe, 1992); Williamson's (1988) inferences on the trajectory of the Ijaw in eastern Nigeria; and Lewis' (2015) identification of settlement and migratory patterns of populations in North Edo, western Nigeria. It should be noted that these works have focused largely on prehistoric migrations, leaving out aspects like prehistoric identity. For instance, there is the contest of ethnocultural and political 
pre-eminence between the ancient Ife and Bini empires of Nigeria to which this paper lends linguistic evidence.

It often happens that languages with multitudes of speakers occupying vast expanses of land and wielding political blocs enjoy overwhelming prestige above cohabiting languages with tiny populations of native speakers. Often, also, the attitudes which derive from such linguistic imbalance are so pervasive as to permeate spheres of language choice and use, even to notions of chronological pre-eminence of a language with a large population of native speakers over that of a language with a small group of speakers. This state of affairs is more likely when the language with the advantage is properly codified and standardized. That is the case in southwestern Nigeria, where the minority and largely un-codified Edoid languages of the Bini are often taken to be recent offshoots of the Yoruboid stock. To the extent that, Yoruboid, a huge language family with a cluster of nineteen varieties (considered as dialects because of their homogeneity ${ }^{1}$ ), is perceived as parent of Edoid, which is comprised of thirty heterogeneous languages (See Figs. 2 and $2 b)^{2}$.

The force of political appropriateness between Bini and Ife has been strong enough to occlude phylogenetic facts which plot Edoid above Yoruboid in West Benue-Congo (Williamson and Blench 2000: 31, figure 1). In fact, it is popularly expressed in larger Nigerian society that the Edoid speak more recent versions of Yoruba. However, since 2004, there have been fierce verbal and written exchanges between monarchs and leaders on both sides of the divide; each claiming diachronic precedence over the other. Following from this backdrop, this paper assesses linguistic evidence to test the original question about which of Edoid and Yoruboid precedes the other.

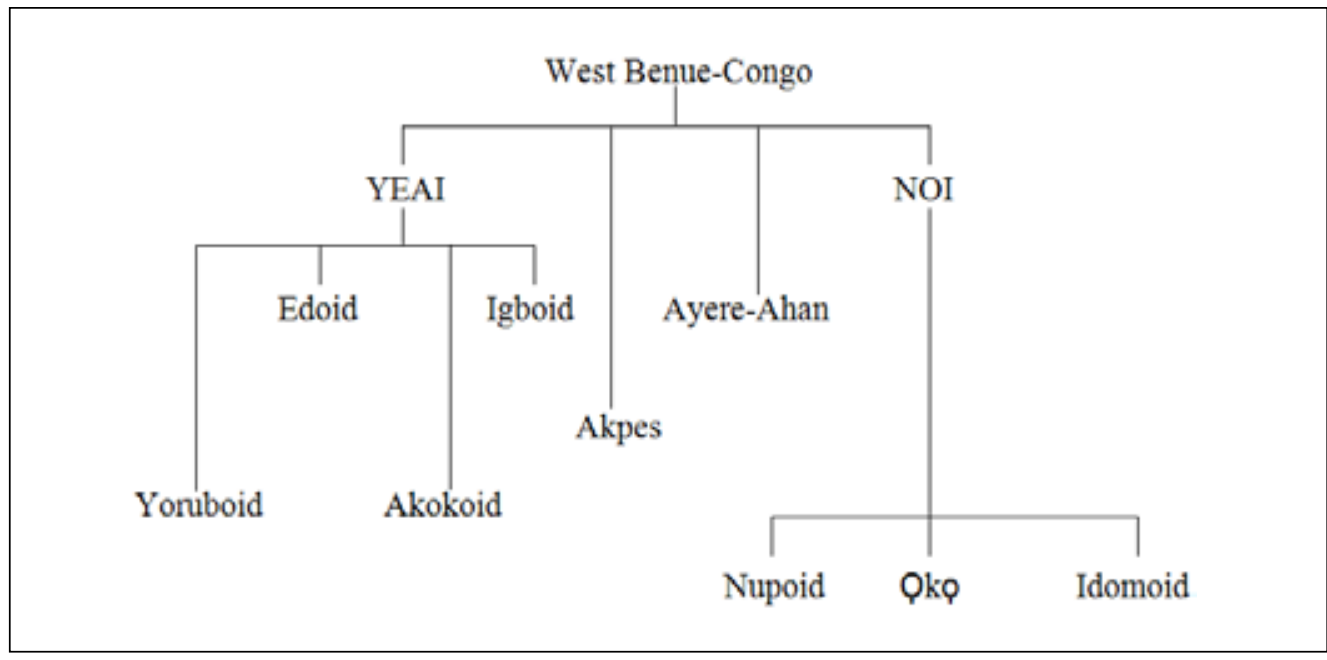

Figure 1: Classification of West Benue-Congo Language (Williamson and Blench, 2000: 31)

\footnotetext{
1 Yoruba is referred to as homogeneous because its varieties are intelligible along a dialect chain. The varieties of Edoid are, however, heterogeneous because they are mutually unintelligible and distinct languages.

2 In figure 2a, aside from Ife, all of Ondo, Ogun, Lagos, Ekiti and Oyo are Yoruboid. The Edoid languages from which data were drawn are indicated in figure $2 b$.
} 


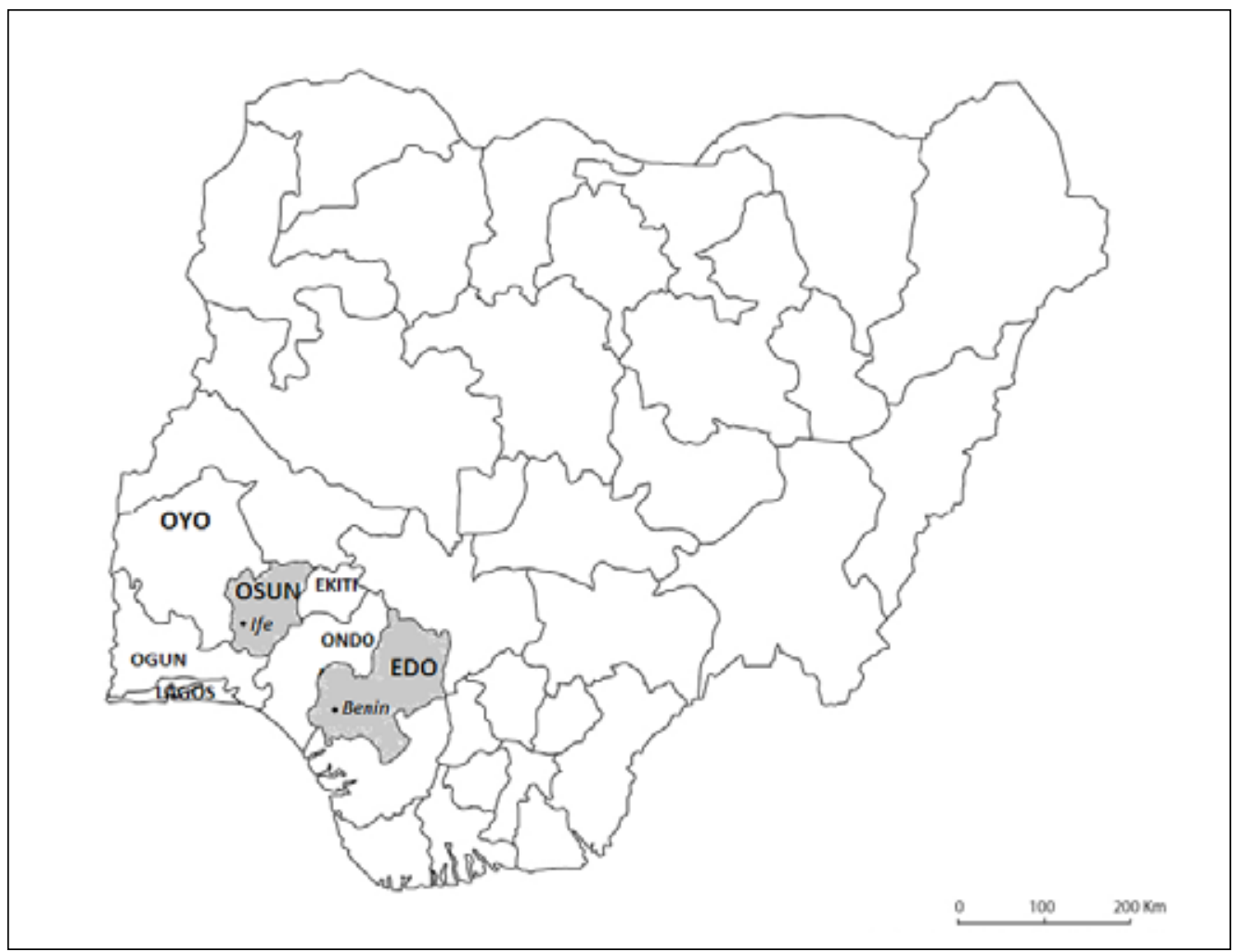

Figure 2a: Map of Nigeria showing Ife (Uhe) and Benin (Bini)

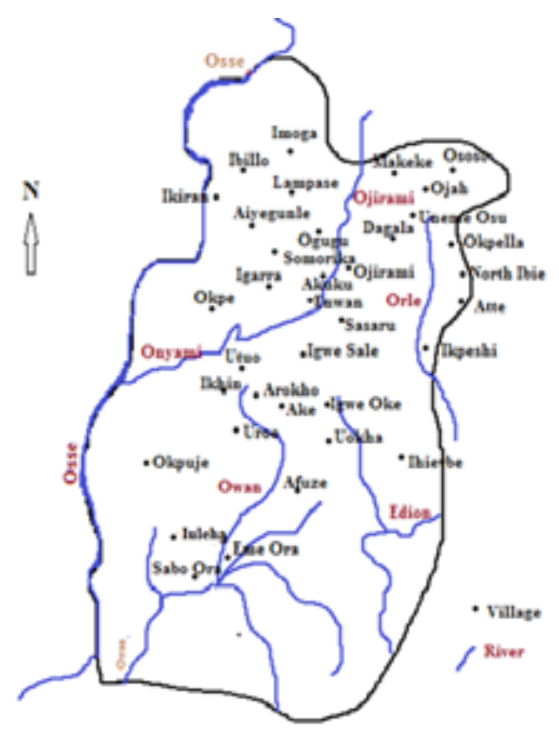

Figure 2b: Map of Northern Edo showing relevant villages/languages

(C) Lewis and CMDR. 2018 


\section{ORAL TRADITION ON THE BINI-IFE PRE-EMINENCE CONTESTATION}

Both the Bini and the Ife people believe that a prince of Ife went to rule Bini in the $12^{\text {th }}$ century AD. The points at issue are that of the lineage of the said prince and whether his ascension to the throne was the origin of the Bini or a mere change of dynasty.

\section{The position of the Oba of Benin}

The mistake that modern historians (including Yoruba) made, as I have found from my own studies, is that they confuse Oduduwa with Orumila, the bringer of Ifa divination.

\section{Omo N'Oba N'Edo UkuAkpolo Kpolo Oba Erediauwa, Sunday Vanguard 9 May, 2004.}

According to the Oba of Benin, Omo N'Oba N'Edo UkuAkpolo Kpolo Erediauwa, the prince of Ife that took the Benin throne was the son of a runaway Bini prince, Ekaladerhan, whom the Yoruba knew as Oduduwa and rightly claim to have come from the east - Bini being more easterly than Ife. He maintained that Bini and Ife were founded by two of the sixteen coequal sons of Orunmila; and that the first dynasty of Bini kings was known as Ogisi. There were thirty Ogisi until Ogisi Owodo, who by a diktat of the oracle was compelled to execute his only son. However, unknown to Ogisi Owodo, the executioner spared the life of the son and let him escape into a bush, onwards to Ife (Uhe as the Bini call it). At Ife, this prince of Benin gained popularity for his healing prowess, to the extent that he was made king by consensus after a popular revolt sent the village head packing. Thus, news reached Bini about the exploits of their crown prince, but when their emissaries eventually caught up with Ekaladerhan, he was already the Yoruba king, Oduduwa. Seeing as it was not possible for the aged Oduduwa to abdicate the Ife throne and ascend that of Bini, he sent his last son, Oranmiyan, to become king at Bini. It was at that time that the Bini dynasty changed title from Ogisi to Oba. Nevertheless, Oranmiyan only ruled for a stint of a few months, after which he abdicated the throne in anger, largely from cultural shock. However, the dumb son of Oranmiyan, who was cured by an Ife babalawo, eventually became Oba Eweka I of Benin, thus continuing the dynasty of Oba from Oranmiyan to date.

\section{The position of the Ooni of Ife}

The Oba of Benin whose dynasty commenced in 1191 AD was an Ife Prince borrowed to the people of Benin (sic) on their request, after the rule of the Ogisos' ended in Benin history... The Oba of Benin should go and read what his fore-fathers told the Portuguese explorers during their visit to Benin on $2^{\text {nd }}$ July 1550 AD about the relationship between Ife and Benin. So, it is too late for the Omo N'Oba to rewrite our history.

Oba Sijuade, Ooni of Ife Vanguard, Friday 7 May, 2004

In his account, the Ooni of Ife vehemently dissociated Oduduwa from the Ogisi dynasty of Bini, insisting that since Oranmiyan was loaned to Bini as Oba, upon dying, the head of every Bini Oba was buried at the sacred place of Orun-Oba-Ado in Ife up until 1900. As 
an extension of the authority of Ife over Bini, the Ooni cited archival records which made clear that the Ooni of Ife had to authorise the installation of new Bini king up to 1916. This position got the backing of historians including Ade Ajayi, who asserts that the father and predecessor of the Omo N'Oba regularly attended the conference of Yoruba Obas and did not object to the fact that the founder of Bini was an Ife prince (The Sunday Vanguard, 9 May, 2004).

\section{Merging the two oral traditions}

Whereas the Yoruba maintain that a prince of Ife founded the Bini kingdom, the Bini do not lay claim to founding the Yoruba kingdom. As the Omo N'Oba made clear, Bini and Ife populations hail from a common Orunmila source. Instead, the Bini claim that their fugitive crown prince, by some twist of events, became king at Ife. It was this same Ife Oba of Bini origin that sent a prince, Oranmiyan, to be king at Bini, at the request the Bini, who wished to end an interregnum by reinstating exiled royal lineage. The Yoruba story therefore perfectly fits into the Bini narrative, which accounts for a levelpegged beginning of both Bini and Ife populations as descendants of Orunmila and provides an explanation for the trajectory of Oduduwa before his advent in Ife. It would therefore seem that these Ife and Bini oral traditions told the same story, each as far as it was known to them from different periods in history.

\section{METHODOLOGY}

The thrust of the study was to identify which of Yoruboid or Edoid is replete with more complex forms of cognate words and etyma of cultural vocabulary.
Based on this premise, decisions had to be taken on, which varieties of Edoid and Yoruboid languages had representative complexities to warrant comparison; what kinds of lexicon were rich in archaisms and what framework of analysis would best illustrate the complexities being sought.

\section{Selection of languages}

The selection of languages to compare was hinged on the results of previous studies. On the grounds of possession of archaic features and high linguistic differentiation, and following the inklings of Williamson (1988), Northwestern Edo, comprising North Edoid languages, has been postulated as the Edoid cradle (Elugbe 1989: 24; Lewis 2013: 239). These studies established that Edo (Bini), despite being the official and most widely spoken language of the Bini Kingdom, has more simplified lexicon than the North Edoid languages. Hence, the North Edoid languages exhibit archaic forms closer to proto-Edoid than does Edo (Bini). This conclusion ties with the age-area principle (Crowley and Bowern, 2010), which affirms that among related languages, remote areas with small populations have high linguistic diversity and archaic features akin to the proto-language, and the areas where these etyma are spoken constitute the homeland of the language group. Hence, whereas Edo Bini is the dominant Edoid language, extant minority languages of North Edoid are closer in form to protoEdoid than Edo (Bini) is. Going by this foregrounding, North Edoid languages provided the best archaic representatives of Edoid words. These Edoid extant forms were, therefore, compared with cognate Yoruboid forms to determine which of Edoid or Yoruboid retain etyma lexicon. 
As already adduced, Yoruboid forms are significantly homogenous. In fact, Yoruboid varieties, with the exception of Itsekiri and Igala, are considered dialects of one language. Hence, the Standard dialect of Yoruba, which is a composite of features of all Yoruba dialects, was used for this study.

\section{Identification of relevant \\ lexicon and phenomena for comparison}

Cultural as well as basic vocabularies were compared in this study. This is because aspects of identity and history of closely related peoples are better embodied in cultural lexicon, just as basic vocabulary also preserve prehistory connections. Hence, the Ibadan 400 wordlist, which aside from having basic vocabulary also has cultural items common to the Benue-Congo language sub-family to which the Yoruboid and Edoid belong, was adopted.

The compared vocabulary items were in four broad categories, namely animate, mundane, occupational and numerical. Animate vocabulary included names for local animals common to Edoid and Yoruboid regions, as well as action verbs proper to humans and animals. Flora, water and heavenly bodies constituted mundane items that were analysed. The occupational vocabulary that was evaluated included smithery, pottery and weaving. These, aside from crop farming and cattle rearing, are the most ancient occupations of both peoples. Some attention was paid to cognate logic in numeration between members of Edoid and Yoruboid. Finally, given that language complexity and simplicity can be gleaned from sound inventory, and the presence of decadence of vowels harmony, Yoruboid and Edoid sound inventories and patterns of vowel harmony were also compared.

\section{Identifying natural linguistic change}

The inspection of the chronological trend of linguistic change was anchored on phonological plausibility, which draws from the hypothesis that speakers tend to simplify linguistic complexities with the passage of time (Hock, 1991; Ohala, 1993; Kirchner, 2000; Kingston, 2008). By implication, older and isolated varieties of languages manifest complex (etyma) forms which have been lost by more recent varieties. Further still, there are well defined directions of sound change which derive from sounds assimilating the features of their phonological environments (Crowley and Bowern, 2010). For instance, there is a universal tendency towards intervocalic voicing, whereby voiceless sounds like [s] become voiced to $[\mathrm{z}]$ when they occur between vowels. Phenomena such as intervocalic voicing are referred to as natural processes. Hence, phonological plausibility is interpreted in historical linguistics as the chronological occurrence of natural processes.

Another characteristic of natural phonological processes is that they usually imply the weakening of sounds, whereby a sound converts to a form which requires less energy for production. This process is referred to as lenition and Hock (1991: 83) provides a detailed intrinsic lenition hierarchy for segments, which is adopted in this study. Some productive leniting processes identified in the data were intervocalic voicing, pre-palatalization, Suffix/prefix deletion, debuccalization (i.e. the changing of oral sounds to $[\mathrm{h}]$ ), spirantization (consonants converting to sibilant fricatives), sonorant alternation (largely $[\mathrm{m}]$ becoming $[\mathrm{w}]$ and vice versa), 
simplification of double articulation, and nasalization.

Within the context of cultural vocabulary, items with cognate forms were scoured for archaisms. We first explored natural sound changes across cognate cultural and occupational vocabularies, especially those involving lenition (the appearance of weaker sounds from strong ones) and contraction of lexicon by deletion of sounds and clipping of syllables. Thus, etyma lexicons are determined largely on the bases of strength of sounds and complexity of words. Chronological preference was also given to non-derived words over derived words (composed by compounding or phrase nominalisation).

\section{EVALUATION OF ANIMATE DATA}

Five sets of animate data were analysed. The separation is more for expository force than for categorical distinctions. We compared Edoid and Yoruboid cognates to see which of the two groups provides overwhelming number of etyma. Where there are two cognate forms, they are presented and analysed together. After such evaluation, the most complex form is nominated as etymon and indicated with an asterisk. Hence, asterisk in this paper does not indicate reconstructed forms. Furthermore, at the right side of each item in the data, we have indicated the language group, either Yoruboid $(Y o d)$ or Edoid $(E d d)$, to which the etymon is ascribed.

\section{Animate items I}

Consider animate items in example (1). The extant Igwe form ígknàkpè stands out first as the etymon of the word fish in Edoid, where the consonant on the second syllable [g] through lenition and pre-palatalization evolved into $[\gamma, 3, \mathrm{j}]$ as found in Ikhin, Ghotuo and Arokho. By extension, [dz] as manifested in Yoruba, is the first derivative of a combination of pre-palatization and lenition. There has also been a lowering of word initial front vowels from [i] to $[\varepsilon]$. The same vowel lowering process is repeated between Uroe and Yoruba in the word for meat, just as a velar plosive has become a palato-alveolar fricative in $d o g$. (1)

\begin{tabular}{|c|c|c|c|c|c|c|}
\hline Fish & $\begin{array}{l}\text { Igwe*1 } \\
\text { igćnàkpè }\end{array}$ & $\begin{array}{l}\text { Ghotuo } \\
\bar{e} \text { zìe }\end{array}$ & $\begin{array}{l}\text { Ikhin } \\
\text { èyà }\end{array}$ & $\begin{array}{l}\text { Arokho } \\
\bar{e} j \bar{e} \quad \grave{e} h \dot{\varepsilon}\end{array}$ & $\begin{array}{l}\text { Uroe } \\
\qquad \overline{\varepsilon d} \mathrm{~d}^{\mathrm{a}}\end{array}$ & $\begin{array}{l}\text { Yoruba } \\
E d d\end{array}$ \\
\hline Dog & $\begin{array}{l}\text { Ihievbe* } \\
\text { ágwà }\end{array}$ & $\begin{array}{l}\text { Ikpeshi } \\
\bar{\imath} d z \hat{a}: d_{3} i\end{array}$ & $\begin{array}{l}\text { Okpella } \\
\text { áwà }\end{array}$ & & & $\begin{array}{l}\text { Yoruba } \\
\bar{a} d z a ́ \quad E d d\end{array}$ \\
\hline Meat & $\begin{array}{l}\text { Uroe* } \\
\text { íràmì }\end{array}$ & $\begin{array}{l}\text { Ake } \\
\text { ćjàmì }\end{array}$ & $\begin{array}{l}\text { Arokho } \\
\text { ćrà }\end{array}$ & & & $\begin{array}{l}\text { Yoruba } \\
\overline{\varepsilon r a ̃ a} E d d\end{array}$ \\
\hline & $\begin{array}{l}\text { Okpamheri } \\
\text { Ėdo }\end{array}$ & $\begin{array}{l}\text { Ikpeshi } \\
\text { ¿̇d }\end{array}$ & $\begin{array}{l}\text { Ososo } \\
\grave{a} d \grave{j}\end{array}$ & & & $\begin{array}{l}\text { Yoruba } \\
\text { cd ’ (liver) }\end{array}$ \\
\hline Horse & $\begin{array}{l}\text { Okpella* } \\
\text { át } \int_{1}^{1}\end{array}$ & $\begin{array}{l}\text { Ikpeshi } \\
\bar{a} t \int \bar{l}\end{array}$ & $\begin{array}{l}\text { Ikhin } \\
\overline{\varepsilon \mathrm{S}} \overline{1}\end{array}$ & & & $\begin{array}{l}\text { Yoruba } \\
\varepsilon \widetilde{\tilde{1}} E d d\end{array}$ \\
\hline Blood & $\begin{array}{l}\text { Okpe* } \\
\text { àt }\end{array}$ & $\begin{array}{l}\text { Ghotuo } \\
\text { àd ̀̀ }\end{array}$ & $\begin{array}{l}\text { Akuku } \\
\hat{a}: z \grave{\varepsilon}\end{array}$ & $\begin{array}{l}\text { Igwe } \\
\text { àt }\end{array}$ & & $\begin{array}{l}\text { Yoruba } \\
\dot{\varepsilon d} \bar{\varepsilon} E d d\end{array}$ \\
\hline
\end{tabular}

3 Asterisks indicate the form considered as etymon of the set. 
In addition, the Yoruba forms for fish and meat have undergone suffix deletion. In fact, there is a trace of the suffix nasal $[\mathrm{m}]$ in $\bar{\varepsilon}$ rã, Yoruba for meat. It is remarkable that the alternative form for meat which dominates Ediod is èdò, which in contemporary Yoruba refers to liver. It could be mutually argued either that Yoruba has narrowed the meaning of $\grave{\varepsilon}$ d’̀ or that Edoid groups have extended its meaning. We subscribe to the latter by reasoning that it is less plausible for a generic name like that of a pervasive item like meat to be reduced to a small part of its referent. Thus, غ̀dò 'liver' may be referred to as meat, but $\bar{\varepsilon}$ rã̃ 'meat' may not be referred to as liver.

The words for Horse and blood present already attested palatalzation $\left(/ \mathrm{t} /\right.$ to $\left[\mathrm{d}_{3}\right]$ and $\left.[\mathrm{f}]\right)$, occasioned by front vowels. They also have in common the raising and fronting of word initial [a] in Okpella and Okpe to $[\varepsilon]$ in Yoruba. Both processes simplify in the direction of Yoruba and the cognates cut across Edoid groups.

(2)

\begin{tabular}{|c|c|c|c|}
\hline Neck & $\begin{array}{l}\text { Okpella* } \\
\text { ùtùri }\end{array}$ & $\begin{array}{l}\text { Ghotuo } \\
\overline{\varepsilon w} \bar{r} \bar{y}^{-}\end{array}$ & $\begin{array}{l}\text { Uokha } \\
\bar{u} r \bar{u}\end{array}$ \\
\hline Hand & $\begin{array}{l}\text { Ikpeshi* } \\
\text { ùbóxj̀ }\end{array}$ & $\begin{array}{l}\text { Enwa } \\
\text { óbjyi }\end{array}$ & $\begin{array}{l}\text { Igwe } \\
\text { wóbj }\end{array}$ \\
\hline Friend & $\begin{array}{l}\text { Ikhin* } \\
\text { láméré }\end{array}$ & $\begin{array}{l}\text { Arokho } \\
\text { órè }\end{array}$ & \\
\hline Cow & $\begin{array}{l}\text { Akuku } \\
\text { ìmànú: }\end{array}$ & $\begin{array}{l}\text { Atte } \\
\text { mànú: }\end{array}$ & \\
\hline Tail & $\begin{array}{l}\text { Uroe* } \\
\bar{u} k p u ́ r u ́ m u ́ \partial ̀ i\end{array}$ & $\begin{array}{l}\text { Igwe } \\
\text { úrúāhh̃̀ }\end{array}$ & $\begin{array}{l}\text { Ikhin } \\
\text { irù }\end{array}$ \\
\hline Push & $\begin{array}{l}\text { Warake* } \\
\text { jtói }\end{array}$ & $\begin{array}{l}\text { Ghotuo } \\
\text { ti }\end{array}$ & \\
\hline Grind & $\begin{array}{l}\text { Uroe* } \\
\text { ílómè }\end{array}$ & $\begin{array}{l}\text { Ikhin } \\
l 5^{-}\end{array}$ & \\
\hline Elephant & $\begin{array}{l}\text { Okpella* } \\
\text { éni }\end{array}$ & $\begin{array}{l}\text { Ikpeshi } \\
\text { éni }\end{array}$ & \\
\hline & $\begin{array}{l}\text { Akuku } \\
\text { ânàsà }\end{array}$ & $\begin{array}{l}\text { Ogbe } \\
\text { ánàzà }\end{array}$ & \\
\hline
\end{tabular}

\section{Animate items II}

All the items in (2) display clipping in the form of prefix or suffix deletion or both - CVC, VC and V. There is a tendency for Edoid back vowel $[\mathrm{u}]$ to descend to [o] in Yoruba in word initial position, as instantiated in body parts hand and neck. Lenition in hand takes the form of approximation to labial-velar glide [w]; receiving the velar component from the back quality of flanking vowels.

Aside from prefix deletion, item cow manifests an inter-language alternation of alveolar [n] and [1]. Again, based solely on the criterion of strength, Edoid [n] predates Yoruboid [1]. There are two cognate forms for elephant - àdzànà̀kú and éni. Both are used as synonyms in Yoruba, but in Edoid terrain, the first is restricted to northern Akoko-Edo, whereas the other is used in southern Owan. It should also be noted that àdzànà̀kú represents one of the few instances where the etymon is extant in Yoruba and prefix deletion occurs in the Edoid forms. As for the éni -form, the nasal $[\mathrm{n}]$ lenited to $\left[\mathrm{r}^{\sim}\right]$, leaving a nasal trace on the following vowel.

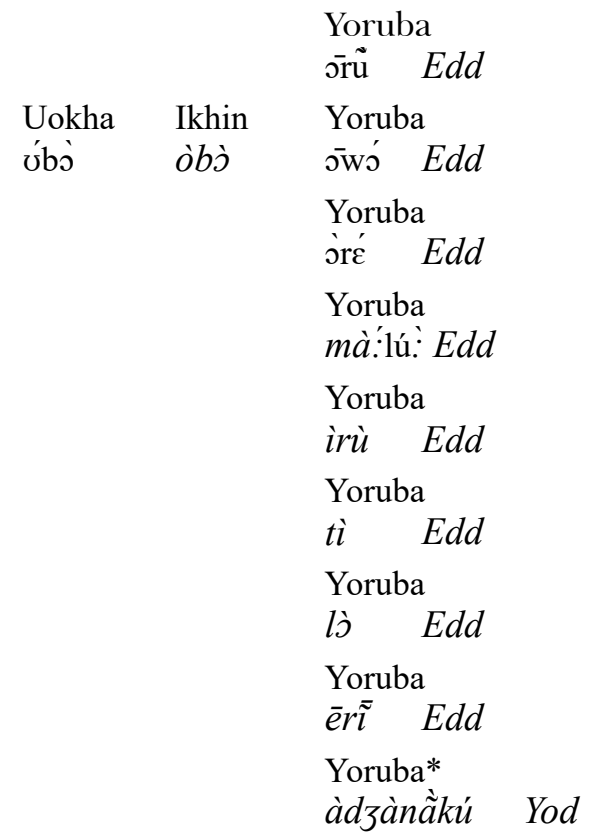




\section{Animate items III}

Item woman or wife in (3) has suffix deletion plus lenition. The latter leads up to debuccalization in the direction $\mathrm{s} \sim \mathrm{z} \sim \mathrm{j} \sim \mathrm{h}$ to produce Okpe [ohāmī]; and the Yoruba form has [j] which is an intermediate development. As for cat, its voiceless labial-velar plosive became voiced intervocalically; and there was also suffix deletion. The item $H e$-goat again instantiates chronological debuccalization. This time however, the process progresses in the direction of Edoid, culminating in the loss of segment in Arokho, while Yoruba has the etymon. Item feather seems opaque to chronological inferences, save for the fact that the front vowels $[\mathrm{e}]$ and $[\varepsilon]$ may have caused [g] to become [b], the latter being an anterior consonant. It may also be relevant to add that both bilabial [b] and velar [g] are acoustically grave (Jakobson and Halle 1956).

(3)

\begin{tabular}{|c|c|c|c|c|}
\hline Woman/Wife & $\begin{array}{l}\text { Atte* } \\
\text { òsàmhì }\end{array}$ & $\begin{array}{l}\text { Ikpeshi } \\
\text { jzàmì }\end{array}$ & $\begin{array}{l}\text { Okpe } \\
\text { गhām } \bar{\imath}\end{array}$ & $\begin{array}{l}\text { Yoruba } \\
\overline{a j} \text { jāìjàwó Edd }\end{array}$ \\
\hline Cat & $\begin{array}{l}\text { Ikhin* } \\
\text { ólókpèrērè }\end{array}$ & $\begin{array}{l}\text { Arokho } \\
\text { ullékpèrè }\end{array}$ & $\begin{array}{l}\text { Ghotuo/Uroe } \\
\text { ólógbò }\end{array}$ & $\begin{array}{l}\text { Yoruba } \\
\text { ōlógbò }\end{array}$ \\
\hline He-goat & $\begin{array}{l}\text { Okpella } \\
\text { jwúh5- }\end{array}$ & $\begin{array}{l}\text { North Ibie } \\
\text { owùxj }\end{array}$ & $\begin{array}{l}\text { Arokho } \\
\text { Éwiè }\end{array}$ & $\begin{array}{l}\text { Yoruba* } \\
\bar{e} \text { wúrć/obúk̄̄ “ }\end{array}$ \\
\hline Feather & $\begin{array}{l}\text { Ghotuo } \\
\text { úgégé }\end{array}$ & $\begin{array}{l}\text { Sasaru } \\
\text { ùrērēe }\end{array}$ & $\begin{array}{l}\text { Ikhin } \\
\text { àbēbé }\end{array}$ & 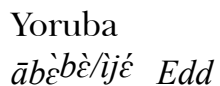 \\
\hline
\end{tabular}

\section{Animate items IV}

In (4), the item come displays a clear lenition and transition of voiced bilabial plosive [b] through the labio-dental to the labial-velar place. There is a conversion from fortis to lenis between Uneme and Atte, then spirantization shift to labio-dental place to yield [v] in Warake and Okpuje, followed by approximation to [v] in Okpella, and finally a change of place to labial-velar in Yoruba. Item hold displays a simple case of suffix deletion with the same kind of sonorant alternation between $[\mathrm{m}]$ and [w] that is observed in drink - yet a case of a bilabial stop surfacing as a labial-velar

approximant. The situation is however a little more complex with the item drink; whereas the Yoruba form has the [m] which becomes [w] in Edoid Okpe and Arokho, even with a nasal trace on the succeeding vowel, Okpe has preserved the unclipped form of the word. There is an interesting demonstration of strengthening in the development of the word for die. North Ibie has a labial-velar approximant in word initial position, which inches up the strength scale as a debuccalized fricative in Ora; and alternatively, as a voiced plosive in Akuku, then as a devoiced plosive in Yoruba. 
(4)

\begin{tabular}{|c|c|c|c|c|c|c|}
\hline Come & $\begin{array}{l}\text { Uneme }^{*} \\
\text { ábádì̄- }\end{array}$ & $\begin{array}{l}\text { Atte } \\
\text { bhàle }\end{array}$ & $\begin{array}{l}\text { Warake } \\
\text { òvádè }\end{array}$ & $\begin{array}{l}\text { Okpella } \\
\text { vàrē }\end{array}$ & $\begin{array}{l}\text { Okpuje } \\
\text { vàè }\end{array}$ & $\begin{array}{l}\text { Yoruba } \\
\text { wá } \quad E d d\end{array}$ \\
\hline \multirow[t]{2}{*}{ Hold } & Ikhin* & Arokho & Uroe & & & Yoruba \\
\hline & $m u ́ p \bar{m} \varepsilon$ & úwว̀rēer & ūmói & & & mú Edd \\
\hline \multirow[t]{2}{*}{ Drink } & Okpe* & Arokho & & Ghotuo & & Yoruba \\
\hline & jíwวิ๋wù & $w \grave{\tilde{\partial}} \hat{:}$ & & $w \bar{u}$ & & $m \bar{u} \quad E d d$ \\
\hline \multirow[t]{2}{*}{ Die } & Akuku & \multirow{2}{*}{\multicolumn{2}{|c|}{$\begin{array}{l}\text { North Ibie* } \\
\text { wù }\end{array}$}} & Ora & & Yoruba \\
\hline & gù & & & $h \grave{u}$ & & $k u ́ \quad E d d$ \\
\hline
\end{tabular}

\section{Other items of diachronic relevance}

The words for sea, one and leopard in (5) expose a curious development involving the simplification of double articulation to yield a sequence of singly articulated plosive and a nasal vowel [kṽ)]. It would seem that the loss of labial articulation is facilitated by velar lowering; such a process again validates the age-long acoustic link between bilabial and velar articulations (Jakobson and Halle 1956). There is a trade-off between suffix and prefix deletion in rope (see Igwe and Yoruba). Igwe is more archaic only because it has a longer form. As is often the case, Yoruba has deleted the suffix and prefix for small. The caveat with rope is that even non-Benue-Congo Hausa has Keremi, suggesting that the word could be Nupoid in origin (borrowed from Nupe slave traders). The etymon for flower is conceded to Ghotuo for the simple fact that there is no natural reason for high front vowel [i] to arise from the back vowel reflexes seen in word initial position in the other forms; rather [i] more plausibly was pulled back by the assimilatory effect of vowels in the second and third syllables.

(5)

\begin{tabular}{|c|c|c|c|c|}
\hline Sea & $\begin{array}{l}\text { Arokho* } \\
\text { ókpédà }\end{array}$ & $\begin{array}{l}\text { Uroe } \\
\text { ókpćdíċ }\end{array}$ & $\begin{array}{l}\text { Igwe } \\
\text { oküjélé }\end{array}$ & $\begin{array}{l}\text { Yoruba } \\
\text { ok } \overline{\tilde{u}} \quad E d d\end{array}$ \\
\hline One & $\begin{array}{l}\text { Ikhin } \\
\text { órokpā }\end{array}$ & $\begin{array}{l}\text { Arokho } \\
\text { okpā }\end{array}$ & $\begin{array}{l}\text { Ake } \\
\text { غ̀kpà }\end{array}$ & $\begin{array}{l}\text { Yoruba } \\
\text { jkā Edd }\end{array}$ \\
\hline Leopard & $\begin{array}{l}\text { Okpamheri } \\
\bar{a} k p \dot{\varepsilon}\end{array}$ & & & $\begin{array}{l}\text { Yoruba } \\
\varepsilon \mathrm{ku} \quad E d d\end{array}$ \\
\hline Rope & $\begin{array}{l}\text { Igwe* } \\
\text { wúìrì }\end{array}$ & & & $\begin{array}{l}\text { Yoruba } \\
\text { òwú } / \bar{o} k \dot{u} \quad E d d\end{array}$ \\
\hline Small & $\begin{array}{l}\text { Uroe* } \\
\text { kékérémì }\end{array}$ & $\begin{array}{l}\text { Sasaru } \\
\text { ¡kérèmì }\end{array}$ & & $\begin{array}{l}\text { Yoruba } \\
\text { kékēré } E d d\end{array}$ \\
\hline Flower & $\begin{array}{l}\text { Ghotuo* } \\
\text { iddòdó }\end{array}$ & $\begin{array}{l}\text { Igwe } \\
\text { ūdōdó }\end{array}$ & $\begin{array}{l}\text { Okpuje } \\
\text { ódòdō }\end{array}$ & $\begin{array}{l}\text { Yoruba } \\
\text { òdòdó } E d d\end{array}$ \\
\hline Sharp & $\begin{array}{l}\text { Arokho* } \\
\text { omútàì̀ì }\end{array}$ & $\begin{array}{l}\text { Igwe } \\
\text { jmũ }\end{array}$ & & $\begin{array}{l}\text { Yoruba } \\
\text { mú } \quad E d d\end{array}$ \\
\hline
\end{tabular}


To sum up section 4 , it has been observed that there is an overwhelming assortment of lenition in the direction of Yoruba when compared with Edoid languages. Thus, a huge inventory of etyma supports a predating of Edoid forms over Yoruboid. Along similar lines, on the basis that Yoruba uses two forms for words like meat, feather and elephant, each of which share cognates exclusively with different Edoid groups, it is being proposed that there have been at least two layers of interaction between the North Edoid groups and the Yoruboid. Quite like the Bini narrative, the first layer may have been genetic and the second dynastic. For instance, the links with Owan languages of north Edo seem more recent than those with Akoko-Edo. To buttress this point, there are extant forms of a cognate for cat - olókpèrērè - used only by Yoruba, Ikhin, Ghotuo, Arokho and Uroe. The rest of Owan and Akoko-Edo use músú of Nupoid origin. The fact that the olókpèrērè form is restricted to the Owan axis is a pointer to nascent acquisition. Yoruba also has two forms for cow - crā̃ and mălù - each of which share cognate exclusively with different North Edoid regions: mǎlù is shared with Akoko-Edo languages, while $\bar{\varepsilon} \tilde{a} \overline{-}$ tallies with Owan languages. Like músú, mălù stems from Nupe. These common and exclusive patterns of shared lexicon point to relations reaching back to proto-Benue-Congo.

\section{EVALUATION OF OCCUPATIONAL LEXICON}

The human professional history began with fortuitous hunting and gathering on land, followed closely by fishing.
When populations increased and natural resources began to dwindle, it came time to explore farming and the raising of livestock. Somewhere in-between all of these, pottery developed, largely as a source of household utensils like pots and water containers. Metallurgy came about as tools were needed for farming and more sophisticated hunting, as well as for security. In this section, we investigate items of pottery, weaving and smithery to determine archaisms which may reveal chronological state of affairs between Edoid and Yoruboid.

\section{Inspection of pottery lexicon}

\author{
ikòkò nī bāba ì $i \bar{a} s \grave{u}$ \\ [The cooking pot is the father of pots]
}

(Popular Yoruba saying)

We will approach the discussion on pottery lexicon from the perspectives of cognate simplification, variety of wares and word formation patterns. Pottery is practised today by Edoid as well as Yoruboid natives, more by the latter. Information was gathered from Ojah and Otuo in Akoko-Edo (Edoid) and Ijaye in Abeokuta (Yoruboid). As it turns out, all three towns are situated at the base of hills; and in them, pottery is more associated with the female than with the male gender. Pottery lexicon from the three villages is tabulated. Consider table 1 . 
Table1: Comparative Edoid and Yoruboid pottery lexicon

\begin{tabular}{|c|c|c|c|}
\hline & Gloss & Edoid Langs. & $\begin{array}{l}\text { ljaye } \\
\text { (Yoruboid) }\end{array}$ \\
\hline 1. & Pestle & úrùmù & 5̄məríōdó \\
\hline 2. & Ring like metal & óhámì & \\
\hline 3. & Design comb & otf'́ (úkèlè) & jjà \\
\hline 4. & Carving wood & $\bar{e} k p i$ & gbé \\
\hline 5. & Maize stalk & ègbigirí & kù̃küàgbàdō \\
\hline 6. & Knife & óbc̄rèmmā & j̉beàmò \\
\hline 7. & Shiner & ع́gú:fè & á:'ré \\
\hline 8. & Foundation & ūrôvè & ìkpìlè \\
\hline 9. & Clay & ćrčmmā (òwè) & àṁ̀ \\
\hline 10. & Fire & ínòmì & İnã \\
\hline 11. & Pre-mould & & īgī:rà \\
\hline 12. & Mud pot maker & & ìjámòkpó \\
\hline 13. & Shining pots & & àkpغ̀ \\
\hline 14. & Cooking pot & ūkòdò & ìjāsũ̀ \\
\hline 15. & Herbalist pot & ùxwèlà & $\overline{1} \int \widehat{a}$ sùàsedz로 \\
\hline 16. & Water pot & ghéghéàmè & ikòkòōmī \\
\hline 17. & Big pot & ùlè & āgbēbī \\
\hline 18. & Pot for herbs & & kòlòbō \\
\hline 19. & Pot for solids (swallows) & ùsāì & \\
\hline 20. & Perforated pot & ùbà & \\
\hline 21. & Amala pot & àdàlà & \\
\hline $22 .$. & Sauce pot & lābغ̀ & \\
\hline 23. & Decorative pot & & ذ̀tūégbé \\
\hline 24. & Placenta pot & & ìkòkòìbì̄̄mō \\
\hline 25. & Ash tray, Candle stand & & àtùkpà/ ēkpō \\
\hline
\end{tabular}

In table 1, Items 4, 6, 9 and 10 of table 1 are cognates shared by Edoid and Yoruboid. It can be told even by simple observation that they derive from common ancestral words. What follows is a phonological analysis of each to ascertain directions of innovation.
Item 4: Carving wood

\section{Edoid}

Yoruboid

ēkpí

$\mathrm{gbc}$

Correspondences:

$$
\begin{aligned}
& \mathrm{e} \sim \varnothing \\
& \mathrm{kp} \sim \mathrm{gb} \\
& \mathrm{i} \sim \varepsilon
\end{aligned}
$$

Processes: Intervocalic voicing, followed by prefix vowel elision and final vowel lowering. Innovations are in the direction of Yoruboid. 
Item 6: knife

$$
\begin{aligned}
& \text { Edoid Yoruboid } \\
& \text { óbērèmmā jbēàmò } \\
& \text { ćrèmmā àmò }
\end{aligned}
$$

Correspondences: $\varepsilon \sim \varnothing$

$$
\begin{aligned}
& \mathrm{r} \sim \varnothing \\
& \varepsilon \sim \mathrm{a} \\
& \mathrm{m} \sim \varnothing \\
& \mathrm{m} \sim \mathrm{m} \\
& \mathrm{a} \sim 0
\end{aligned}
$$

Processes: Loss of VC-prefix and

\begin{tabular}{|c|c|c|c|}
\hline $\begin{array}{r}\text { Edoid } \\
\text { inomì }\end{array}$ & & & $\begin{array}{l}\text { Yoruboid } \\
\bar{i} n \tilde{a}\end{array}$ \\
\hline \multirow[t]{5}{*}{ Correspondences: } & $\mathrm{i}$ & $\sim$ & $\tilde{1}$ \\
\hline & $\mathrm{n}$ & $\sim$ & $\mathrm{n}$ \\
\hline & o & $\sim$ & $\tilde{a}$ \\
\hline & $\mathrm{m}$ & $\sim$ & $\varnothing$ \\
\hline & I & $\sim$ & $\varnothing$ \\
\hline
\end{tabular}
deletion of syllabic nasal. Loss of post nasalization and consequent change of vowel quality to the closest auditory equivalent, [o]. $[\varepsilon]$ is also lowered to [a]. Innovations are in the direction of Yoruba

Item 10: Fire

Processes: [i] assimilates the nasal feature from [n], [o] is first nasalized and then centralized by the forward pull of all the sounds in the word, becoming [ã]. [n] deletes the palatal feature, after which word final syllable [mi] is lost. Innovations are in the direction of Yoruboid.

The processes above display such phonological and morphological simplification as to suggest that the Yoruba words are more recent derivatives. They are upshots of natural processes, shorter in form and less complex than their Edoid equivalents.

\section{Word formation patterns in pottery}

It was observed that a number of items in table 1 were derived by description. Given that there is usually no logical correspondence between the signified and the signifier in language, it follows that most words formed by description are applied to items otherwise alien to speakers of the language. Both groups have words so derived, but they are more on the side of Yoruboid. Consider (6). (6)

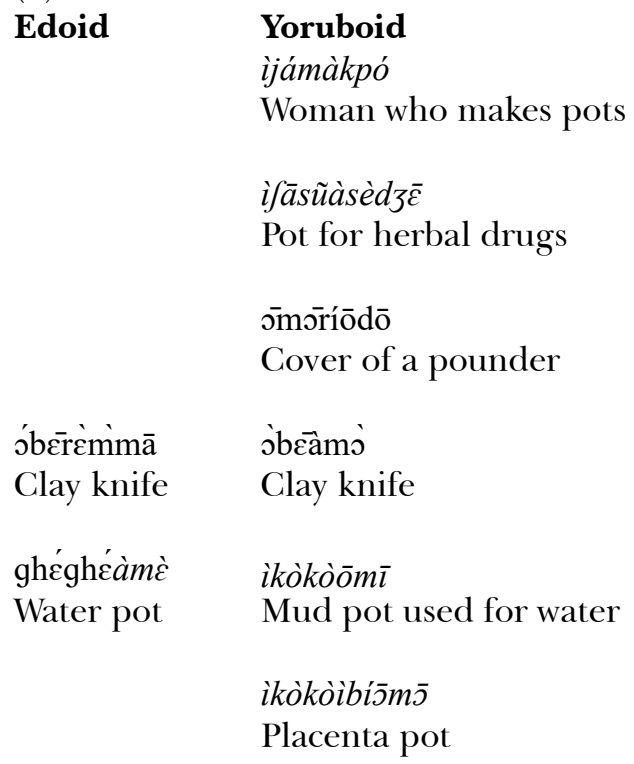

It should be noted that the Edoid have non-derived native words for many of the items for which Yoruba gives descriptive names. The presence of more descriptive words for pottery items in Yoruba is an indicator of the fact that the trade is nascent and imported.

There is an extension of meaning in the use of ikoko by the Yoruba. Whereas its cognate equivalent in Ghotuo (Edoid) refers only to cooking pot, the Yoruba meaning of ikòkò is a generic name for pots. To clinch the argument in favour 
of Edoid, consider the teaser at the beginning of this section: ikòkò babāi isầ [The cooking pot is the father of pots].

The statement portrays two generic words for pot in Yoruba, ikòkò and ifāsũ. The first form, ikokò, is cognate with Edoid $\bar{u} k \dot{d} d \grave{o}$, while the second term does not feature in Edoid vocabulary. Indeed, the translation of ikokò as cooking pot stems from the Edoid cognate word. The fact that $\bar{u} k \dot{d} d \dot{o}$ is more archaic than ikòk is self evinced from the likelier development of $[\mathrm{k}]$ from $/ \mathrm{d} /$ when the former is flanked by high back vowels and there is an identical velar plosive in the preceding syllable. Now, Yoruba uses îāsu $\tilde{u}$ and ikòkò as generic synonyms for pot (see items 15, 16 and 24 on table 1). If this pattern is anything to go by, the ùkòdò-ikòkò cognate would be prehistoric and $i f \bar{a} s \hat{\tilde{u}}$ would be a recent Yoruba term deriving from other contacts. Should that be the case, it would follow that

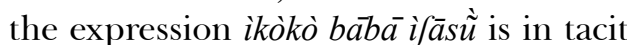
admittance of Edoid pre-eminence.

It would then be plausible that occupational pottery is prehistoric to the Edoid. The Yoruba either share this homeland with the Edoid, or they acquired pottery by recent contact. Natives of Ojah speak of times back in the day when the main export of Ojah was pottery. Meanwhile, at this time, pottery is scarcely practiced in NorthWestern Edo, and ornamental pottery is the mainstay of many present Yoruba settlements. The vast majority of sound simplifications in pottery vocabulary occur in the direction of Yoruboid. Thus, pottery assessment again points to Edoid ancient and Yoruboid nascent practices.

Another dimension to word formation pattern in pottery pertains to the variety of pots. Items 13 to 25 in table 1 are names for different pots. Whereas both groups have names for cooking, water, herbalist and big pots; it is indicative that other kinds of pots belong exclusively either to Edoid or Yoruboid groups.

The Edoid on the one hand have exclusive pots based on their functionality; such as sauce pot, swallows pot (for solid food eaten with sauce), meat dehydrating pots (perforated to serve its purpose) and ámàlà pot (items 22, 19, 20 and 21). Just as well, there are Edoid traditional practices attached to the pots. For instance, women are not permitted to dip hands in the iláḃ sauce pot. Rather, women may only use a traditional spoon to scoop sauce from the pot. If a woman must dip her hand in a sauce pot, her husband must clear her curse by dipping his own hand in before her.

On the other hand, pots peculiar to Ijaye are ornamental objects of contemporary art. The sole exception is the kòlobò which contains medicinal herbs. As for the placenta pot, ikòkoibísmō, which seemingly performs a traditional function, it may yet be argued that neither Yoruboid nor Edoid groups bury placenta in a pot. There is no ritual associated with the burying of placenta. It is done in a hurry and in utmost secrecy,lest someone other than the child's father discovers the place it was interred. Thus, like the ash tray and other ornamental pots, the placenta pot is one more recent invention. Hence, the kinds of pots restricted to the Edoid have traditional functionality. They are designed with little aesthetic character and have deep cultural relevance. Such traditionally functional pots are absent in Ijaye pottery, where the pots are more ornamental and made as artefact rather than household tools.

The other side of the pottery tale is that of numbers. Ijaye is currently a beehive of pottery activities. It is in fact the major preoccupation of women in 
the entire town. Such extensive practice of a profession is symptomatic of recent acquisition. The exact opposite scenario obtains in Edoid regions, where only vestiges of a glorious pottery industry now exist in a few villages far between. Pottery, certainly, was not a bequeathal by the Yoruboid to the Edoid. Indeed, evidence is accruing in support of an Edoid antecedent to Yoruboid pottery. In fact such patterns have been prescribed as suggestive of homeland as instantiated in the spread of corded ware ceramics across Europe. Kossina (1902) as reported in Renfrew (1988 [1994]: 36), for instance, postulates Indo-European homeland as NorthCentral Europe, based on archaeological finds of a high concentration of corded ware pots which are sparse in other parts of Europe. He argues that the area of concentration is the homeland, and that the pots were transported to other parts of Europe by groups which migrated away from the homeland. This interpretation ties neatly with the agearea hypothesis advanced by Crowley and Bowern (2010: 13), which stipulates that the overwhelming presence of any phenomenon is suggestive of recent development. In the context of this paper, it would imply that pottery is a more recent occupation of Yoruboid than Edoid natives. This suggestion calls for archaeological excavation to confirm the spread of peculiar pottery.

\section{Inspection of lexicon for weaving}

Cloth and basket weaving are practised in Edoid as well as Yoruboid lands. The people of Ososo are renowned for weaving in Akoko-Edo, while Iseyin is just as famous in Yorubaland. As with pottery, however, weaving is contemporarily more widespread in Yorubaland. The items in table 2 are drawn largely from Ibadan list of 400 words.

Table 2: Comparative Edoid and Yoruboid weaving lexicon

\begin{tabular}{|c|c|c|c|}
\hline & Gloss & Edoid & Yoruboid \\
\hline 1. & Weave & mū & hũ̃/wũ \\
\hline 2. & Tie & İkpárì/gć & dì/sō \\
\hline 3. & Cloth & ūfē/úkpò (Ikhin) & $\bar{a} \int \bar{\jmath}$ \\
\hline 4. & Gown & ह̀wù & ह̀wù \\
\hline 5. & Thread & úlè/ówù & òwú \\
\hline 6. & Needle & úrùmè/édùnè/ákpèdè (Ikhin) & ābéré \\
\hline 7. & Rope & úrì/wúìì (Igwe) & ōkũ̀ \\
\hline 8. & Red & ólj̀lj̀/sàì & kpūkpā \\
\hline 9. & Black & Óbìbì & Dúdú \\
\hline 10. & Yellow & ānēré & ìjèjè/ànũ̀rí \\
\hline 11. & Dye (Guinea corn) & āzīkù & āró \\
\hline
\end{tabular}


Interestingly, many weaving terms are cognate between both groups - items 1, 3, 4, 5, 6 and 10. Indeed, item 4 and 5, غ̇wù $\sim$ and òwú, have exact forms both ways.

Item 1: Weave

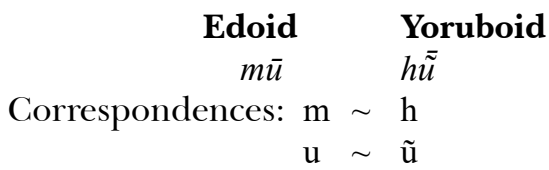

Process: Quite like the pattern observed with Edoid sounds, [m] debuccalizes to [h] leaving a nasal trace on the succeeding vowel. Innovations are in the direction of Yoruboid.

Item 3: Cloth

$\begin{aligned} & \text { Edoid } \text { Yoruboid } \\ & \text { ufe } a \oint \\ & \text { Correspondences: } \mathrm{u} \sim \mathrm{a} \\ & \int \sim \int \\ & \mathrm{e} \sim \mathrm{J}\end{aligned}$

Process: The vowel substitution seems rather intractable. Pre-eminence may only be conceded to the Edoid form on the grounds that high front vowel [e] is responsible for the emergence of [S] from some other consonant, after which the Yoruboid form substituted vowels.

Item 6: Needle

$\begin{aligned} & \text { Edoid } \text { Yoruboid } \\ & \text { akpede } \text { abcre } \\ & \text { Correspondences: } \mathrm{a} \sim \mathrm{a} \\ & \mathrm{kp} \sim \mathrm{b} \\ & \varepsilon \sim \varepsilon \\ & \mathrm{d} \sim \mathrm{r} \\ & \varepsilon \sim \varepsilon\end{aligned}$

Processes: The simplification of labial-velar plosive [kp] results in [b] via loss of velar component. Voiced alveolar plosive [d] also lenites to approximant $[\mathrm{r}]$ in intervocalic position. Both processes have the weaker sound as Yoruboid.
Item 10: Yellow

\begin{tabular}{|c|c|c|c|}
\hline $\begin{array}{c}\text { Edoid } \\
\text { anere }\end{array}$ & & & $\begin{array}{l}\text { Yoruboid } \\
\text { ijeje }\end{array}$ \\
\hline Correspondences: & $\mathrm{a}$ & $\sim$ & $\mathrm{i}$ \\
\hline & $\mathrm{n}$ & $\sim$ & j \\
\hline & e & $\sim$ & $\mathrm{e}$ \\
\hline & $\mathrm{r}$ & $\sim$ & j \\
\hline & $\mathrm{e}$ & $\sim$ & $\mathrm{e}$ \\
\hline
\end{tabular}

Processes: An Edoid palatal nasal surfaces in Yoruboid as an approximant of the same place, while an alveolar approximant sandwiched between high front vowels switches to the palatal place. Visible innovations are on the Yoruboid side.

Every case of cognation has the etymon in Edoid, suggesting that the Edoid have linguistic precedence.

\section{EVALUATION OF COGNATE NUMERATION}

Low numerals constitute basic vocabulary (Swadesh 1952). They also reflect collective logic. Language is logic. Therefore, common counting systems betray common thought patterns and cognate worldview. In this section, Edoid counting systems are compared with Yoruboid in anticipation of ancestral revelations.

\section{Counting strategies}

Tables 3 and 4 summarize counting patterns for North Edoid languages and Yoruba. It would be observed from them that all the systems operate at base ten numeration. In addition to that, Akoko-Edo languages employ an addition strategy up to numeral 20. Yoruba alone subtracts from 20 while counting 15 to 19 (i.e. numerals 15 to 19 are 20 less five, 20 less four etc.) consistently, and multiples of 20 (50 for instance is 60 less 10 etc.). The Owan languages subtract from 20 to count 16 to 19 , but not for numeral 15 , 
which is counted as $\bar{l}$ gbihjè $(10+5)$ in Uroe for instance. Whereas Yoruba subtracts ten from multiples of twenty to count 50, 70, 90, all the Edoid add 10 to the preceding multiples of twenty to count same. Curiously, the Uneme count 100 as a multiple of fifty; while all other groups conceive it as twenty multiplied by five.

Table 3: Summary of numeral patterns in Yoruba and North Western Edoid Languages

\begin{tabular}{|c|c|c|c|c|c|c|}
\hline Numbers & Yoruba & Okpamheri & Uneme & Ososo & Akuku & Ọkpẹ \\
\hline 1 & $j k \overline{\tilde{a}}$ & joú & jkpá & oghuo & ogu & áwô \\
\hline 10 & غ̀wá & īgbé & $\bar{I} g b e ́$ & īgbé & īgbé & īgbé \\
\hline $11-14$ & Addition & Addition & Addition & Addition & Addition & Addition \\
\hline $15-19$ & Subtraction & Addition & Addition & Addition & Addition & Addition \\
\hline 20 & ogứ & j́gbj̀l’́ & $u w \varepsilon$ & jógẁ̀lı & ú:jiè & lijè \\
\hline \multirow[t]{2}{*}{30} & $\bar{\jmath} g b \grave{\partial}$ & ó:gbj̀lítègbè & j̀gbà & j̀gwòljànítégbé & & j́gbj̀ \\
\hline & & $20+10$ & & $20+10$ & $20+10$ & \\
\hline 40 & $20 \times 2$ & $20 \times 2$ & $20 \times 2$ & $20 \times 2$ & $20 \times 2$ & $20 \times 2$ \\
\hline \multirow[t]{2}{*}{50} & Subtraction & Addition & Addition & Addition & Addition & Addition \\
\hline & $60-10$ & $40+10$ & $40+10$ & $40+10$ & $40+10$ & $40+10$ \\
\hline 60 & $20 \times 3$ & $20 \times 3$ & $20 \times 3$ & $20 \times 3$ & $20 \times 3$ & $20 \times 3$ \\
\hline \multirow[t]{2}{*}{70} & Subtraction & Addition & Addition & Addition & Addition & Addition \\
\hline & $80-10$ & $60+10$ & $60+10$ & $60+10$ & $60+10$ & $60+10$ \\
\hline 80 & $20 \times 4$ & uhe & $20 \times 4$ & uhe & $20 \times 4$ & $20 \times 4$ \\
\hline \multirow[t]{2}{*}{90} & Subtraction & Addition & Addition & Addition & Addition & Addition \\
\hline & $100-10$ & $80+10$ & $80+10$ & $80+10$ & $80+10$ & $80+10$ \\
\hline \multirow[t]{2}{*}{100} & & & Ègbólísèlúkpòlévà & & & \\
\hline & $20 \times 5$ & $20 \times 5$ & $50 \times 2$ & $20 \times 5$ & $20 \times 5$ & $20 \times 5$ \\
\hline
\end{tabular}

Table 4: Summary of numeral patterns in North Central Edoid Languages

\begin{tabular}{|c|c|c|c|c|c|c|}
\hline Numbers & Igwe Sale & Ikhin & Ake & Arokho & Uroe & Ghotuo \\
\hline 1 & כ̃:wò & órj̀kpā & غ̇kpà & $\bar{j} k p a ́$ & jkppâ & $\grave{k} k p \bar{a}$ \\
\hline 10 & īgbé & ìgbè & ìgbè & īgbé & ìgbè & ìgbé \\
\hline $11-15$ & Addition & Addition & Addition & Addition & Addition & Addition \\
\hline $16-19$ & Subtraction & Subtraction & Subtraction & Subtraction & Subtraction & Subtraction \\
\hline 20 & úwòhē & ùwè & úwغ̀ & újè & Úrè & úwègè \\
\hline 30 & j́gbà̀ & $\grave{g} g b \grave{~}$ & ógbà & j̄gbà & ógbà & $\bar{\jmath} g b \bar{a}$ \\
\hline 40 & $20 \times 2$ & $20 \times 2$ & $20 \times 2$ & $20 \times 2$ & $20 \times 2$ & $20 \times 2$ \\
\hline
\end{tabular}




\begin{tabular}{lllllll}
\hline 50 & Addition & Addition & Addition & Addition & Addition & Addition \\
& $40+10$ & $40+10$ & $40+10$ & $40+10$ & $40+10$ & $40+10$ \\
60 & $20 \times 3$ & $20 \times 3$ & $20 \times 3$ & $20 \times 3$ & $20 \times 3$ & $20 \times 3$ \\
70 & Addition & Addition & Addition & Addition & Addition & Addition \\
& $60+10$ & $60+10$ & $60+10$ & $60+10$ & $60+10$ & $60+10$ \\
80 & $20 \times 4$ & $20 \times 4$ & $20 \times 4$ & $20 \times 4$ & $20 \times 4$ & $20 \times 4$ \\
90 & Addition & Addition & Addition & Addition & Addition & Addition \\
& $80+10$ & $80+10$ & $80+10$ & $80+10$ & $80+10$ & $80+10$ \\
100 & $20 \times 5$ & $20 \times 5$ & $20 \times 5$ & $20 \times 5$ & $20 \times 5$ & $20 \times 5$ \\
\hline
\end{tabular}

\section{Cognate numeration evidence}

Words for numerals 1, 3, 4, 10, 20 and 30 are cognate across the board. Yoruba jkã (one) is a derivative of Uneme jkpá, in which a labial-velar plosive deletes the labial aspect for more efficient articulation. Similar simplifications manifest in Okpamheri joú (voicing, fronting and approximation), Ososo oghuo (voicing and lenition), Akuku ogu (voicing and loss of labial feature), Okpe áwô (approximation).

Consider the following vigesimal evidence. Across the Edoid groups of Akoko-Edo, numerals twenty and thirty are represented with derivatives of ogbo. Certainly, all of Owan use ogbo for thirty and Yoruba uses the same form. It seems fortuitous until you consider the fact that the Okpamheri (Ososo and Uneme) word for thirty is o:gbolítègbè (twenty plus ten). The fact is Yoruba and some Edoid languages retain only a clipped form of the full word for thirty. Such clips are replete in Yoruba and Owan numerals. The question then arises, why do Yoruba and Owan languages not use ogbo for twenty? Rather, the words are $\overline{o g u ́ u} \#, \dot{u} w \bar{c}, u_{j} e_{\text {, }}$ which would pass as derivatives of ogbo, following the deletion of the labial aspect of the [gb] to give [g] and corresponding rise of adjacent vowels that are pulled up by a velar force, plus evidence of approximation (see example 7).

Some North Edoid languages (Ake, Arokho, Ghotuo) indicate numeral 20 with cognate terms like úwè, újè, úwègè etc. but switch to $\mathrm{gbb}+10$, and multiples of ogbo when counting 30,40 etc. This pattern indicates that terms other than ogbo, when used to represent 20 , are recent innovations that do not transcend the entire numeral system. We can tentatively assume that these isolates arose by areal diffusion. It is also a fact that subtraction strategy is diffusing northward as only Yoruba and Owan languages manifest it, no Akoko-Edo language yet subtracts. It is evident that 20 (úwè) surfaces as $\varepsilon g b a$ in counting 60 to 90 across Owan. Thus, there is no consistent form for twenty, yet all the variants are derivatives of $g b$ as shown in (7), where the consonant innovation from ogbo through ogu, $u w \varepsilon$, uje is summarized.

$$
\gamma \beta \underset{\text { delabialization }}{\rightarrow} \quad{ }_{\text {devoicing }}^{\rightarrow} \quad \underset{\text { approximation }}{\rightarrow} \underset{\text { palatalization }}{\rightarrow} \mathrm{j}
$$


It is evident from tables 3 and 4 that cognate counting systems cut across Edoid populations. They share addition patterns with Yoruba uniformly, for low numerals, and subtraction strategy only partially. Terms for 10, 20 and 30 are also cognate. Yoruba and Owan subtraction strategy is an innovation that came about as a result of the loss of the numeral logic for 30, which Yoruba and Owan retain as ogbo (a clipped form of $\mathrm{gbo}+10)$. Again, Edoid counting systems seem more ancient.

\section{COMPLEXITY-SIMPLICITY IN SOUND INVENTORY}

It is axiomatic that language usage results in simplicity from age to age. Some speculations as to the cradle of human life point in the direction of East Africa. Linguistic evidence quite supports this notion on the grounds that African languages display a lot more complexities than European languages. For instance, the use of pitch in lexical and grammatical significance is sophistication unmatched by European languages, which deploy pitch only as phrasal morphemes and in stress. This section is dedicated to drawing lines of complexity and simplicity between Edoid and Yoruboid, in sound inventory and vowel harmony.

\section{Consonant inventory}

In Section 4 it was established by analyses of vocabulary that etyma are retained in contemporary Edoid languages. Further evidence in support of Edoid's chronological advantage include presence of implosive / $/ \mathrm{p} /$ as well as the preponderance of nasal $[\mathrm{m}$, $\mathrm{n}, \mathrm{n}, \mathrm{n}]$ and fricative phonemes in Edoid (tables 5 and 6). The Yoruba sound inventory (Akinkugbe 1978: 63) is a lot simpler. There is just one nasal phoneme $/ \mathrm{m} /$, while continuants $/ \mathrm{v}, \mathrm{v} /$ non-continuant $/ \mathrm{r} /$ and a robust array of non-phonemic proto- and extant sounds like $[\beta, z, 3]$ are markedly absent. Thus, there is more pattern congruity in extant Edoid inventory than obtains in Yoruba. Indeed, as tables 5 and 6 show, Edoid consonant inventory subsumes that of Yoruboid as there are no sounds in Yoruboid not present in Edoid, but the reverse case is different.

Table 5: Proto-Edoid Consonant Phonemes (Lewis 2013: 148)

\begin{tabular}{|c|c|c|c|c|c|c|c|}
\hline & Bilabial & Lab-Dent & Alveolar & Palatal & Velar & Glottal & Labial-Velar \\
\hline Nasal & $\mathrm{m}$ & & $\mathrm{n}$ & $\mathrm{n}$ & & & \\
\hline Velarised Nasal & & & & & $\mathrm{y}^{\mathrm{w}}$ & & \\
\hline Plosive & $\mathrm{b}$ & & $d$ & & $\mathrm{k} \quad \mathrm{g}$ & & $\mathrm{kp}$ \\
\hline Labialised Plosive & & & & & $\mathrm{g}^{\mathrm{w}}$ & & \\
\hline Implosive & 6 & & & & & & \\
\hline Taps & & & r & & & & \\
\hline Cntrl. Fricative & & $\mathrm{v}$ & S & & $\mathrm{x}$ & $\mathrm{H}$ & \\
\hline Cntrl. Approx. & & $v$ & $\mathrm{r}$ & & & & \\
\hline Lateral Approximant & & & 1 & & & & \\
\hline
\end{tabular}




\section{Vowel inventory and harmony}

With respect to vowel harmony, both Edoid and Yoruboid are at different levels of decadence; yet Edoid still edges out Yoruboid in antiquity, as high minus Advance Tongue Root (ATR) vowels [I, $\mathrm{U}]$ are still in common use. Thus, Edoid vowel harmony still functions in the main like Proto-Benue Congo (Fig. 3a), where only vowels of the same ATR value may co-occur in simple words, and [a] may co-occur with both plus and minus ATR vowels. Example (8) shows Edoid-like ATR harmonic alternations between Ibilo (North Western Edoid) and Ghotuo (North Central Edoid).

(8)

Alternation of ATR Vowel Harmony between Ghotuo and Ibilo

\begin{tabular}{|c|c|c|}
\hline Gloss & Ghotuo & Ibilo \\
\hline Eight & enie & $\varepsilon$ nic \\
\hline Leaf & obe & vbc \\
\hline Wash & fue & for \\
\hline Dig & gua & gua \\
\hline Four & eеne & $\varepsilon \varepsilon n \varepsilon$ \\
\hline
\end{tabular}

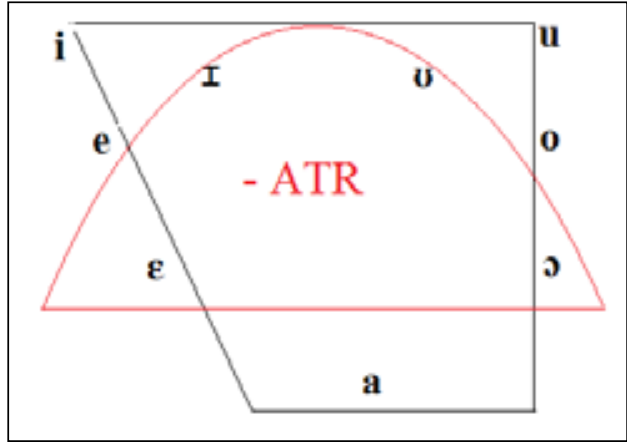

Figure 3a: Proto-Benue-Congo/Edoid Cooccurring oral vowels
(9)

Mid-Vowel Co-occurrence Restriction in Yoruba

$\begin{array}{ll}\text { Gloss } & \text { Yoruba } \\ \text { Narrative } & \text { edzo } \\ \text { Snake } & \text { edzo } \\ \text { Week } & \text { os } \varepsilon \\ \text { Month } & \text { ofu } \\ \text { Cloth } & \text { a j } \\ \text { Poem } & \text { ewi }\end{array}$

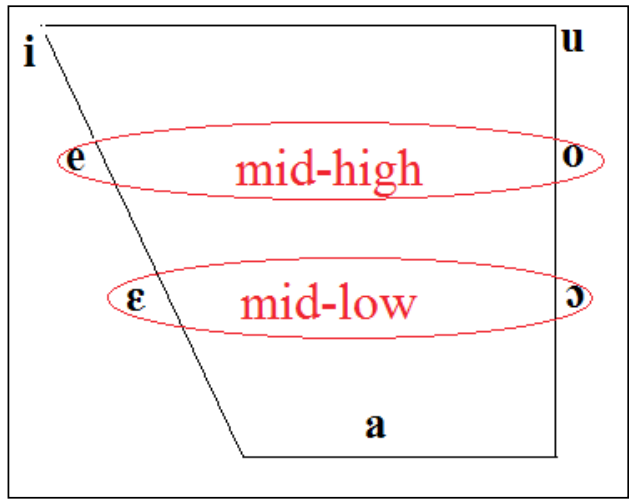

\section{Figure 3b: Yoruba Co-occurring Oral Mid-Vowels}

The current state of vowel harmony in Standard Yoruba (example 9) largely displays ATR co-occurrence restrictions only among mid vowels (Fig. 3b). Consequently, within a simple word, a mid-high (+ART) vowel may occur only with another mid-high (+ATR) vowel or with vowels in the high and low extremities. In like manner, a mid-low (-ATR) vowel may co-occur with another mid-low (-ATR) vowel or with vowels in high and low extremities. Thus, Standard Yoruba has nearly completely neutralized the ATR contrast between close vowels [i] and [I], now rendered as [i]; and [u] and [0], now rendered as $[\mathrm{u}]$. Since the ATR indifference does not involve mid vowels, the plus versus minus ATR dichotomy still stands; hence the harmony among mid vowels. However, irrespective of the coincidence in ATR 
criterion for vowel harmony in Edoid and Yoruboid languages, harmony is manifestly more robust in Edoid languages due to the prevalence of high vowels in the -ATR category.

\section{CONCLUSIONS}

The comparison of Edoid-Yoruboid cognate lexicon showed that etyma lexicon is predominantly found in Edoid forms. This strongly indicates that Edoid languages chronologically predate Yoruboid by being closer in form to Proto-Benue-Congo. There are instances where Yoruboid has two words for an item; sharing one exclusively with Edoid languages in the northern extremities of Akoko-Edo, and the other form, again, exclusively with southern and more proximate Edoid languages of Owan. We interpret this pattern to mean that enduring genetic links are betrayed by lexicon shared by Yoruboid and AkokoEdo (North Western Edoid) in the northern periphery; while those terms shared by Yoruboid and North Central Edoid are as a result of diffusion, given that Owan and Yoruboid populations are contiguous.

In the category of occupational vocabulary, it was found that Edoid traditions have preserved pottery for functionality while Yoruboid traditions have traded off functionality for aesthetics and ornamentation. This is reflected in the morphology of wares. Given that wholesale production traditions are similar, it is not farfetched to link both industries. For that matter, diminishing pottery fortunes in North-Western Edo counterpointed by widespread practice of the industry in Yorubaland paint a typical scenario of source and successor between Edoid and Yoruboid pottery correspondingly.
In comparative Edoid-Yoruboid numeration, it was found that subtraction strategy for numerals 16 to 20 , as well as the substitution of numeral 30 with ogbo occur in the south-north direction. It was also established in Section 6.2 that the current terms in Owan and Akoko-Edo for numeral 20 are derivatives of the current AkokoEdo term ogbo. It therefore follows that the conversion of the term to referent of 20 is a more recent development.

The current sound inventory of Edoid contains some sounds like $\left[\mathrm{g}^{\mathrm{w}}, \mathrm{x}, \mathrm{y}\right]$, which are not currently attested in Yoruba, but were originally included in Akinkugbe's (1978) inventory of Proto-Yoruboid sounds. Indeed the current Edoid sound inventory subsumes all of proto- and contemporary Yoruboid sounds. The fact that these sounds are yet replete in Edoid, while only vestiges are found in Yoruboid groups, while unveiling archaic links, also reveals that Edoid inventory is more ancient.

By the foregoing, lexical and segmental archaisms underscore the fact that contemporary Edoid populations speak more ancient versions of the common West Benue-Congo linguistic heritage. Therefore, the persuasion is that Edoid languages predate Yoruboid, at least in their present states of complexity or lack thereof. It is desired that the present assemblage of sound and lexical evidence tilting to Edoid pre-eminence may invite further prehistoric studies from the disciplines of anthropology, archaeology and art history.

\section{REFERENCES}

Ade Ajayi, J. F. 2004. Yoruba origin controversy, Oba of Benin is playing politics. Sunday Vanguard 9 May: 1.

Akinkugbe, O. 1978. A comparative phonology of Yoruba dialects, Itsekiri and Igala. Unpublished PhD dissertation. Ibadan, Nigeria: University of Ibadan. 
Blust, Robert 1995. The prehistory of the Austronesian-speaking peoples: A view from language. Journal of World Prehistory 9 (4): 453-510.

Crowley, Terry and Bowern, Claire 2010. An Introduction to Historical Linguistics. 4th ed. New York: Oxford University Press.

Elugbe, Ben Ohi 1989. Comparative Edoid Phonology and Lexicon. Delta Series, No. 6. Port Harcourt: University of Port Harcourt Press.

Elugbe, Ben Ohi 1992. The scramble for Nigeria: A linguistic perspective, An Inaugural Lecture, Ibadan: University of Ibadan Press. Rpt. 2011. Ibadan: DB Martoy Books.

Greenberg, Joseph 1963. Languages of Africa. Bloomington: Indiana University Press.

Guthrie, Malcolm 1971. Comparative Bantu: An Introduction to the Comparative Linguistics and Prehistory of the Bantu Languages. 4 vols. Farnborough: Gregg Press.

Heine, B. 1979. Some linguistic observation on history of West Africa. Sprache and Geschichte in Africa 1:37-54.

Hock, H.H. 1991. Principles of Historical Linguistics. Berlin: Mouton de Gruyter.

Horton, R. 1982. The Niger-Kordofanian diaspora: another aquatic saga? Research Seminar Paper. University of Port Harcourt.

Jakobson, R. and M. Halle 1956. Fundamentals of Language. The Hague: Mouton.

Kingston, J. (2008). Lenition. Selected Proceedings of the $3 r d$ Conference on Laboratory Approaches to Spanish Phonology. L. Colantoni and J. Steele Eds.
Somerville, MA: Cascadilla Proceedings Project: 1-31.

Kirchner, R. 2000. Geminate inalteration and lenition. Language, 76, 3: 509-545.

Kossinna, G. 1902. Die Indogermanische frage Archaologisch Beanwortet. Die Urheimat der Indogermanen. Darmstadt: Wissenschaftliche Buchgesellschaft 25-109.

Lewis A. A. 2013. North Edoid Relations and Roots. Unpublished PhD Dissertation. Ibadan: University of Ibadan.

Lewis A. A. 2015. Deciphering aborigines and migrants from cognation and topography in North-Western Edo. Lengua y Migracion 7 (1): 29-52.

Oba Sijuade, Ooni of Ife 2004. How Oba of Benin Goofed. Vanguard, Friday 7 May: 16.

Obomeghie, W. ed. 2013. The Benin-Ife Controversy; Clash of Myths of Origin. Nigeria: Wadorm Communications

Ohala, J. J. 1993. The phonetics of sound change, In C. Jones (ed.), Historical Linguistics: Problems and Perspectives. London: Longman. 237-278.

Omo N'Oba N'Edo UkuAkpolo Kpolo Oba Erediauwa. The Benin-Ife Connection. Sunday Vanguard 9 May: 14.

Swadesh, M. 1952. Diffusional cumulation and archaic residue as historical explanations, Southwestern Journal of Anthropology 7: 1-21.

Williamson K. 1988. The Pedigree of Nations. Inaugural Lecture, University of port Harcourt Press.

Williamson K. and Blench R. 2000. NigerCongo. African Languages, An introduction, B. Heine and D. Nurse Eds. Cambridge: Cambridge University Press. 